\title{
Identifikasi \\ Barcode \\ Tumbuhan \\ Gedi \\ Merah (Abelmoschus manihot L. medik) dan Gedi Hijau (Abelmoschus moschatus) Berdasarkan Gen matK
}

\author{
Yusuf R. Fattaha, Vanda S. Kamua, Max R.J. Runtuwenea \\ Maureen Kumaunanga*, Lidya I. Momuata \\ aJurusan Kimia, FMIPA, Unsrat, Manado
}

\begin{tabular}{l}
\hline K A T A K U N C I \\
\hline Tumbuhan gedi \\
matK \\
DNA barcoding \\
in silico
\end{tabular}

\begin{abstract}
A B S T R A K
Gedi (Abelmoschus L.) merupakan tumbuhan tropis. Tumbuhan ini memilki efek farmakologis. Masyarakat Minahasa mengkonsumsi daun gedi yang direbus tanpa diberi bumbu sebagai obat tradisional untuk menurunkan kadar kolesterol, antihipertensi dan antidiabetes. Suatu metode baru untuk mengidentifikasi dan menganalisis keanekaragaman genetika spesies telah dikembangkan dengan menggunakan potongan gen standar yang dikenal dengan teknik DNA barcoding. Salah satu gen yang terdapat pada tumbuhan yaitu gen matk telah digunakan sebagai gen standar untuk barcoding. Pada penelitian ini telah dilakukan isolasi DNA total dan gen matK penanda barcode DNA dari gedi merah dan gedi hijau, serta analisis in-silico terhadap produk gen matK gedi merah, gedi hijau, dan kerabat terdekatnya. Gen matK diisolasi dan diamplifikasi menggunakan metode Polymerase Chain Reaction (PCR) menggunakan primer forward (5'-CGTACAGTACTITGTGTI ACGAG-3') dan primer reverse (5'-ACCCAGTCCATCTGGAAATCTTGGTTC-3'). Hasil pengurutan nukleotida DNA barcode matK menunjukkan bahwa sebanyak 828 pb matk berhasil diisolasi untuk tumbuhan gedi merah dan tumbuhan gedi hijau. Urutan nukleotida matk gedi merah dan gedi hijau menunjukkan tingkat kemiripan yang tinggi, yaitu > 95\%. Selain itu, hasil analisis in-silico menunjukkan bahwa protein MatK gedi dan kerabat terdekatnya bersifat hidrofobik.
\end{abstract}

KEYW OR D S

A B S T R A C T

Abelmoschus

matK

DNA barcoding

in silico

Gedi (Abelmoschus L.) is a tropical plant. This plant has the pharmacological effects. Minahasan people consumed boiled gedi without any spices addition to lower cholesterol level, blood pressure, and glucose level. A new method for identifying and analyzing the genetic diversity of species has been developed using standard gene known as DNA barcoding technique. One of the genes found in plants called matK gene was used as standard for DNA barcoding. In this research, identification of DNA barcode of red gedi and green gedi based on matK gene, and in-silico analysis on the matK gene products of red gedi, green gedi, and its closest relatives gedi have been done. matK gene was isolated with Polymerase Chain Reaction (PCR) using forward primer (5'CGTACAGTACTITGTGTITACGAG-3') and reverse primer (5'ACCCAGTCCATCTGGAAATCTTGGTTC-3'). Barcode DNA of red and green gedi showed 828 bp nucleotide sequence based on matK gene. In addition, matK of both gedi showed high similarity, i.e. $>95 \%$. Furthermore, in-silico analysis of MatK gedi and its closest relative showed that this protein is hidrophobic. 


\section{Pendahuluan}

Gedi (Abelmoschus L.) merupakan tumbuhan tropis famili Malvaceae, secara tradisional telah lama dikenal di Sulawesi Utara sebagai tanaman sayuran. Tumbuhan ini memilki efek farmakologis untuk membantu penyembuhan berbagai jenis penyakit (Mamahit dan Sukamto, 2010). Masyarakat memanfaatkan daun gedi yang direbus tanpa diberi bumbu sebagai obat tradisional untuk menurunkan kadar kolesterol, hipertensi dan antidiabetes (Suoth et al., 2013).

Tumbuhan genus Abelmoschus hanya dapat ditemui di daerah beriklim tropik, terutama di Afrika dan Asia. Abelmoschus terdiri dari 15 spesies, di Indonesia hanya dikenal 3 spesies yaitu: Abelmoschus moschatus, $A$. esculentus dan $A$. manihot. Abelmoschus adalah kelompok tanaman herbal dengan pertumbuhan cepat, tinggi tanaman sampai 2 meter, panjang daun $20-40 \mathrm{~cm}$, bentuk daun menjari sebanyak 3-7 helai daun (Bourdy dan Walter, 1992). Abelmoschus menunjukkan kandungan lendir pada daun segar ketika dipotongpotong kecil (Morris, 2006).

Kemajuan teknologi pada bidang biokimia memungkinkan para ahli melakukan rekayasa secara genetika dengan mengubah susunan asam amino pada DNA dari genus tanaman tertentu untuk membuat tanaman yang lebih unggul dalam bidang farmakologi, pangan, dan pertanian (Hidayati dan Dermawan, 2012). Hal ini memungkinkan hilangnya sumberdaya genetika dari genus tanaman yang sebagian besar belum teridentifikasi (Krismawati dan Sabran, 2004). Suatu metode baru untuk mengidentifikasi dan menganalisis keanekaragaman genetika spesies telah dikembangkan dengan menggunakan potongan gen standar yang dikenal dengan teknik (DNA) barcoding (Kress et al., 2005).

Teknik DNA barcoding pada tumbuhan dapat digunakan sebagai identifikasi dan konfirmasi penemuan spesies baru dan monitoring perubahannya dari waktu ke waktu dengan biaya yang efektif. Teknologi barcoding ini hanya bertujuan untuk mengidentifikasi suatu spesies baik hewan atau tumbuhan dengan metode yang efisien (Cowan et al., 2012).

Untuk mengidentifikasi DNA tanaman telah disepakati menggunakan potongan DNA pendek standar yaitu gen ribulosa-1,5-bifosfat karboksilase (rbcL) dan maturase K (matK). Gen pengkode yang di gunakan adalah gen matK karena lebih baik dan lebih akurat dibandingkan gen rbcL untuk mengidentifikasi suatu spesies (Kolondam et al., 2012).

Analisis DNA dapat juga dilakukan dengan cara analisis in-silico, yang dilakukan dengan menggunakan piranti lunak komputer, yang bertujuan untuk mengetahui hubungan antara struktur, fungsi, dan stabilitas suatu protein sebagai produk gen (Radford and Dobson, 1999). Melalui hasil analisis in-silico, dapat diketahui sifat fisikakimia suatu protein, sehingga dapat dijadikan studi pendahuluan mengenai manfaat suatu organisme. Misalnya, tumbuhan gedi yang diketahui mempunyai efek farmakologis, terdiri atas 15 spesies (Mamahit, 2009). Masing-masing spesies memilliki keunggulan tersendiri. Melalui analisis in-silico tentang protein yang ada dalam tanaman gedi, maka dapat dilakukan studi lanjut tentang efek farmakologis tumbuhan gedi.

Berdasarkan penelusuran data publikasi barcode DNA melalui Barcode of Life Database (BOLD) Systems (www.boldsystems.org), belum ada publikasi yang mencantumkan DNA barcode untuk tumbuhan gedi merah (Abelmoschus manihot L). Selain itu juga belum ada publikasi yang mencantumkan urutan nukleotida matK tumbuhan gedi hijau (Abelmoschus moschatus) dalam situs National Center for Biotechnology Information (NCBI).

Berdasarkan tinjauan tersebut, perlu dilakukan pengkodean DNA (DNA barcoding) untuk mengidentifikasi DNA tumbuhan gedi merah dan gedi hijau berdasarkan urutan nukleotida matK. Selanjutnya dilakukan analisis in-silico untuk mengetahui fungsi fisiologis aktif MatK tumbuhan gedi.

\section{Metode}

\subsection{Material}

Peralatan yang digunakan dalam penelitian ini adalah alat-alat gelas, hot plate, tabung Eppendorf, mikropipet, inkubator, sentrifugator, alat PCR (Biometra T-personal, Jerman), elektroforesis, spektrofotometer UV-Vis dan freezer.

Kit untuk isolasi DNA tanaman menggunakan InnUPREP Plant DNA kit (Analytik Jena), primer forward matK-1RKIM-f dan primer reverse matK3FKIM-r (Integrated DNA Technology (IDT), Singapura), master mix untuk PCR GoTaq ${ }^{\circledR}$ Green Master Mix (Promega), agarosa (Merck), akuades, etidium bromida (Merck) dan bufer Tris-borat-EDTA (TBE, Promega).

\subsection{Isolasi DNA Total Gedi}

Jaringan daun gedi merah dan gedi hijau masing-masing diambil 0,004 gram, dimasukan ke dalam tabung Eppendorf kemudian digerus menggunakan penggerus tabung Eppendorf. Sampel daun gedi yang sudah disiapkan dalam tabung Eppendorf diekstraksi menggunakan InnUPREP Plant DNA kit (Analytik Jena) sesuai petunjuk manual, dengan menambahkan bufer lisis dan proteinase $\mathrm{K}$. Kemudian diinkubasi selama 45 menit pada suhu $55^{\circ} \mathrm{C}$. Setelah itu, sel dipisahkan dengan sentrifugasi selama 1 menit pada 12.000 rpm. Supernatan yang diperoleh dilewatkan melalui kolom bermembran. DNA total yang diperoleh dicuci dari sisa-sisa protein dan garam, selanjutnya dielusikan dalam tabung mikro dan disimpan dalam lemari pembeku dengan suhu $-20^{\circ} \mathrm{C}$. 


\subsection{Amplifikasi dengan Polimerase Chain Reaction (PCR)}

Reaksi PCR dilakukan dalam volume total $25 \mu \mathrm{L}$. Komposisi dari reaksi PCR yaitu: DNA templat $2 \mu \mathrm{L}$, Firepol Master Mix 5x 5 $\mathrm{LL}$, primer forward matK-1RKIM-f (5'-CGTACAGTACTTTTGTGTTTACGAG3') $1 \mu \mathrm{L}$, Primer Reverse matK-3FKIM-r (5'-ACCCAG TCCATCTGGAAATCTTGGTTC-3') $1 \mu \mathrm{L}$, dd $\mathrm{H}_{2} \mathrm{O} 16 \mu \mathrm{L}$.

Tahapan dalam proses ampifikasi PCR meliputi: Denaturasi DNA (awal) pada suhu $95{ }^{\circ} \mathrm{C}$ selama 120 detik, i) denaturasi pada suhu $95^{\circ} \mathrm{C}$ selama 30 detik, ii) primer annealing pada suhu $50{ }^{\circ} \mathrm{C}$ selama30 detik, iii) DNA extension pada suhu $72{ }^{\circ} \mathrm{C}$ selama 50 detik. Ketiga tahapan (i,ii,iii) akan berlangsung dalam siklus sebanyak 35 kali, dan tahap akhir final extension pada suhu $72{ }^{\circ} \mathrm{C}$ selama 60 detik.

\subsection{Pengolahan Data Sekuens dan Analisis Data Secara In Silico}

Hasil sekuensing DNA disunting menggunakan software Geneious v5.6. dengan langkah sebagai berikut: bagian awal DNA dihapus kira-kira 30bp. Hasil sekuensing menggunakan primer reverse (matK-R) dilakukan proses reverse and complement kemudian dipadukan dengan hasil sekuens primer forward (matK-F) menggunakan MUSCLE (Multiple Sequence Comparison by Log-Expectation) oleh Edgar (2004). Sepuluh kerabat terdekat dari Abelmoschus yang memiliki kemiripan matK 97-99\% (Tabel 1) dianalisis in-silico, meliputi: analisis sifat fisika kimia, anlisis kandungan asam amino (\%), dan penjajaran matK Abelmoschus menggunakan piranti lunak CliustalX dan divisualisasikan dengan GeneDoc (Ratnasingham and Hebert, 2007). Keakuratan amplifikasi gen target yang diuji yaitu gen matK diidentifikasi melalui BOLD (Barcode of Life Database) Systems. Hasil sekuens dibandingkan dengan GenBank menggunakan BLASTn (Basic Local Alignment Search Tool. Protein; http://blast.ncbi. nlm.nih. gov/Blast.cgi).

Tabel 1. Protein matK dari tumbuhan yang digunakan untuk analisis in-silico

\begin{tabular}{|l|l|l|l|}
\hline No. & Kode protein & \multicolumn{1}{|c|}{$\begin{array}{c}\text { Nama } \\
\text { Protein }\end{array}$} & \multicolumn{1}{|c|}{ Organisme } \\
\hline 1 & AFK09827.1 & maturase K & $\begin{array}{l}\text { Abelmoschus } \\
\text { manihot } L\end{array}$ \\
\hline 2 & ABU85043.1 & maturase K & $\begin{array}{l}\text { Abelmoschus } \\
\text { esculentus }\end{array}$ \\
\hline 3 & ABR14768.1 & maturase K & $\begin{array}{l}\text { Hibiscus } \\
\text { surattensis }\end{array}$ \\
\hline 4 & AAU06170.1 & maturase K & $\begin{array}{l}\text { Pavonia } \\
\text { cauliflora }\end{array}$ \\
\hline 5 & AAU06175.1 & maturase K & $\begin{array}{l}\text { Malvaviscus } \\
\text { arboreus }\end{array}$ \\
\hline 6 & BEA80201.1 & maturase & $\begin{array}{l}\text { Talipariti } \\
\text { tiliaceum }\end{array}$ \\
\hline 7 & BAD89713.1 & maturase & $\begin{array}{l}\text { Talipariti } \\
\text { tiliaceum }\end{array}$ \\
\hline 8 & BAD89703.1 & maturase & $\begin{array}{l}\text { Talipariti } \\
\text { tiliaceum }\end{array}$ \\
\hline 9 & BAD89694.1 & maturase & $\begin{array}{l}\text { Talipariti } \\
\text { glabrum }\end{array}$ \\
\hline 10 & ABR14770.1 & maturase K & Kydia calycina \\
\hline
\end{tabular}

\section{Hasil dan Pembahasan}

\subsection{Amplifikasi dan Sekuensing Gen matK}

Hasil amplifikasi matK gedi merah dan gedi hijau diperlihatkan dalam Gambar 1. Hasil elektroforegram tumbuhan gedi merah dan gedi hijau menunjukkan pita DNA yang terbaca berada di ukuran sekitar 750 - 1000 kb. Keberhasilan amplifikasi dengan PCR dibuktikan dengan proses sekuensing. Hasil sekuensing produk PCR matK gedi merah dan gedi hijau memiliki nilai HQ (high quality) yang baik, berturut-turut sebesar 93,7\% dan 92.7\%. Nukleotida yang terbaca dari hasil sekuensing untuk matK gedi merah maupun gedi hijau adalah $828 \mathrm{pb}$.

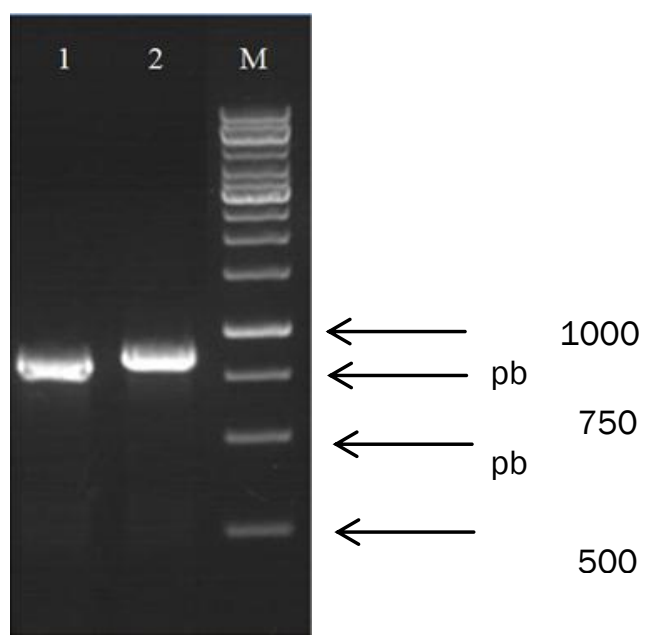

Gambar 1. Elektroforegram hasil amplifikasi matk dengan PCR (1: sampel gedi merah; 2: sampel gedi hijau; M: marker DNA ladder $1 \mathrm{~kb}$ )

\subsection{Barcode DNA Tumbuhan Gedi Merah dan Gedi Hijau}

Barcode DNA gedi merah dan gedi hijau yang ditunjukkan dalam Gambar 2. Dari hasil perbandingan hasil sekuan DNA barcode antara gedi merah dan gedi hijau menunjukan kemiripan yang lestari yaitu sekitar $>95 \%$, dan hanya terdapat perbedaan nukleotida pada permulaan sekuens dan akhir sekuens yang disebabkan pada saat pembacaan sekuen DNA pada proses sequencing fragmen DNA bertumpuk sehingga tidak terbaca oleh sequencer yang ditunjukan dengan warna abuabu pada Gambar 2. Hal ini menunujukan bahwa gen matK pada tumbuhan gedi merah dan gedi hijau memiliki tingkat kemiripan yang tinggi. 


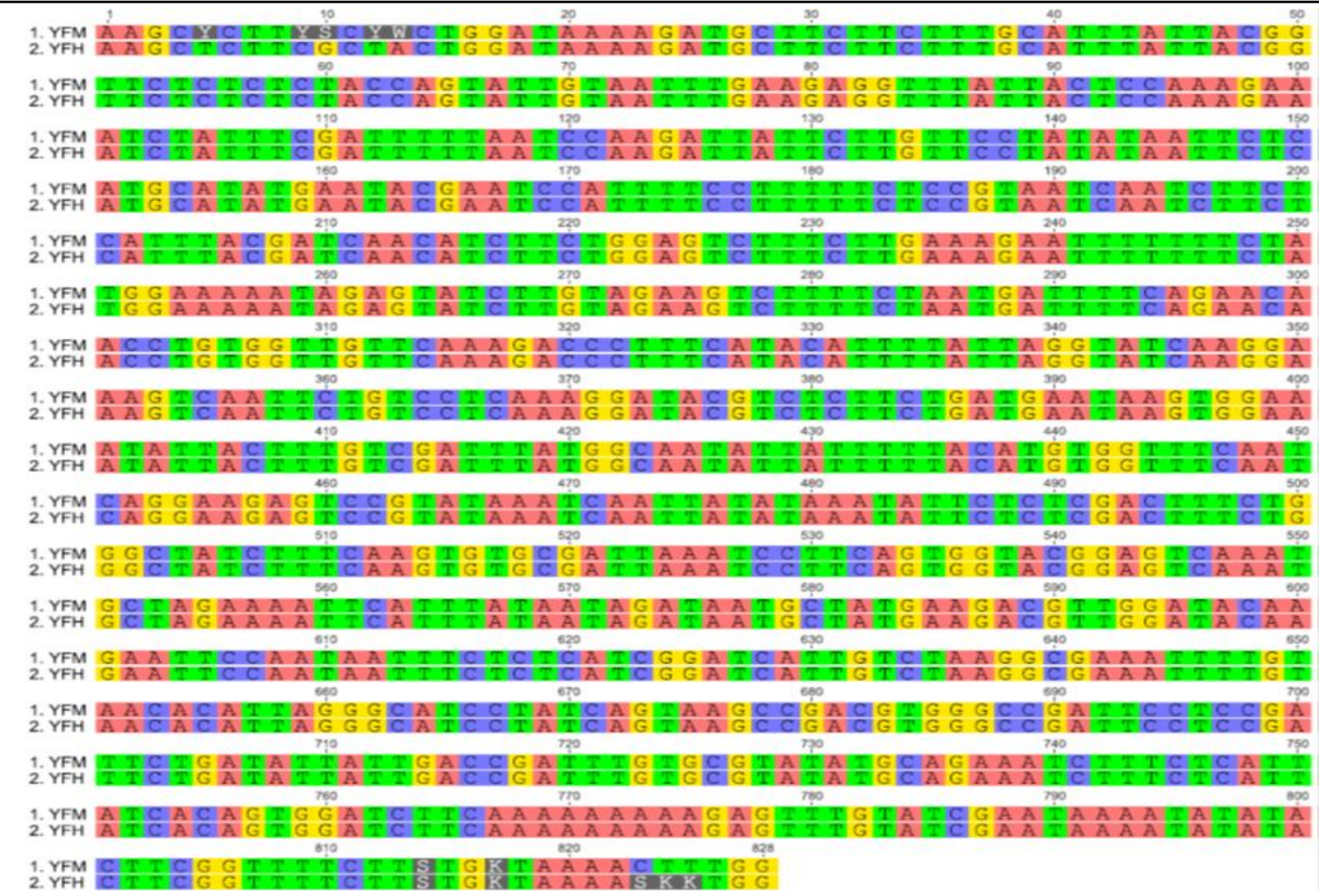

Gambar 2. Perbandingan sekuens DNA bercode dari tumbuhan gedi merah (YFM) dan gedi hijau dengan (YFH).

\subsection{Analisis in-silico}

\subsubsection{Sifat Fisika-Kimia MatK}

Sifat fisika kimia MatK masing-masing organisme (dari Tabel 1) ditampilkan dalam Tabel 2. Sifat fisika kimia yang dari protein matK tumbuhan gedi dengan beberapa tanaman lainnya pada Tabel 2 memperlihatakan berat molekul (BM) dari kesepuluh spesies tersebut berkisar antara
20422,1-59904,1 Da. Kesepuluh spesies tanaman tersebut memiliki nilai isoelektrik (pl) lebih dari 7 yang menunjukan $\mathrm{pH}$ dari suatu protein yang berarti bersifat basa. Dari sepuluh protein matK pada tabel diatas menunjukan nilai GRAVY yang berkisar 0,062 sampai -0,165 yang menunjukan bahwa kesepuluh protein tersebut membentuk ion negatif dan dalam suasana basa yang tidak larut dalam air.

Tabel 2. Hasil Analisis Sifat fisika kimia matk

\begin{tabular}{|l|l|l|l|l|l|l|l|l|}
\hline No & Protein & BM $(\mathrm{Da})$ & $\mathrm{pI}$ & Rumus molekul & JA & II & AI & GRAVY \\
\hline 1 & AFK09827.1 & 20631,8 & 9,61 & $\mathrm{C}_{984} \mathrm{H}_{1436} \mathrm{~N}_{238} \mathrm{O}_{246} \mathrm{~S}_{3}$ & 2907 & 37,91 & 91,62 & $-0,165$ \\
\hline 2 & ABU85043.1 & 69910,2 & 9,51 & $\mathrm{C}_{2779} \mathrm{H}_{4215} \mathrm{~N}_{725} \mathrm{O}_{732} \mathrm{~S}_{13}$ & 8464 & 39,79 & 96,88 & $-0,123$ \\
\hline 3 & ABR14768.1 & 59880,3 & 9,37 & & 8468 & 38,81 & 96,69 & $-0,123$ \\
\hline 4 & AAU06170.1 & 59904,1 & 9,46 & $\mathrm{C}_{2772} \mathrm{H}_{4213} \mathrm{~N}_{725} \mathrm{O}_{737} \mathrm{~S}_{13}$ & 8460 & 40,5 & 96,88 & $-0,145$ \\
\hline 5 & AAU06175.1 & 59793 & 9,48 & $\mathrm{C}_{2774} \mathrm{H}_{4212} \mathrm{~N}_{720} \mathrm{O}_{735} \mathrm{~S}_{12}$ & 8453 & 39,98 & 97,86 & $-0,121$ \\
\hline 6 & BEA80201.1 & 59917,1 & 9,43 & $\mathrm{C}_{2779} \mathrm{H}_{4212} \mathrm{~N}_{720} \mathrm{O}_{739} \mathrm{~S}_{12}$ & 8462 & 39,89 & 96,46 & $-0,145$ \\
\hline 7 & BAD89713.1 & 59869 & 9,43 & $\mathrm{C}_{2775} \mathrm{H}_{4212} \mathrm{~N}_{720} \mathrm{O}_{739} \mathrm{~S}_{12}$ & 8458 & 39,89 & 97,26 & $-0,142$ \\
\hline 8 & BAD89703.1 & 60028,3 & 9,47 & $\mathrm{C}_{2785} \mathrm{H}_{4225} \mathrm{~N}_{723} \mathrm{O}_{738} \mathrm{~S}_{12}$ & 8483 & 40,77 & 97,26 & $-0,143$ \\
\hline 9 & BAD89694.1 & 59929,1 & 9,43 & $\mathrm{C}_{2781} \mathrm{H}_{4216} \mathrm{~N}_{720} \mathrm{O}_{738} \mathrm{~S}_{12}$ & 8467 & 39,89 & 97,26 & $-0,135$ \\
\hline 10 & ABR14770.1 & 20422,1 & 9,21 & & 2684 & 34,41 & 86,05 & $-0,062$ \\
\hline
\end{tabular}

Catatan :Bobot molekul (BM), Titik isoelektrik (pI), Jumlah Asam amino (JA) Indeks ketidakstabilan (II), Grand everage hydropathy (GRAVY).

\subsubsection{Analisis Asam Amino}

Berdasarkan analisis komposisi asam amino matK tumbuhan gedi dengan kerabatnya, terlihat residu asam amino leusin $(\mathrm{L})$ yang tinggi pada masing-masing protein matK dari ke sepuluh tumbuhan yaitu 11,1 \% - 12,3\% residu asam amino.
Sedangakan residu asam amino yang paling redah dari ke sepuluh protein adalah sistein $(C)$ dengan residu asam amino 0,6 \% - 1,2 \%. Pada Protein dengan kode AFK09827.1 (Abelmischus manihot) memiliki residu asam amino fenilalanin $(F)$, lisin $(K)$ dan leusin (L) yang tinggi dari protein lainnya dan tidak memiliki residu asam amino tirosin $(\mathrm{Y})$ dan 
valin (V) yaitu 0,0\%. Berdasarkan pada Tabel 3 sebagian besar residu asam amino memiliki kesamaan antara protein dengan kode AFK09827.1
(Abelmischus manihot) dengan kesembilan protein lainnya.

Tabel 3. Analisis komposisi asam amino matk menggunakan Protparam

\begin{tabular}{|c|c|c|c|c|c|c|c|c|c|c|}
\hline \multirow{3}{*}{$\begin{array}{l}\text { Residu } \\
\text { Asam } \\
\text { Amino }\end{array}$} & \multicolumn{10}{|c|}{ Komposisi Asam Amino (\% mol) } \\
\hline & \multicolumn{10}{|c|}{ Protein matK } \\
\hline & $\begin{array}{l}\text { AFK09 } \\
827.1\end{array}$ & $\begin{array}{l}\text { ABU85 } \\
043.1\end{array}$ & $\begin{array}{l}\text { ABR14 } \\
768.1\end{array}$ & $\begin{array}{c}\text { AAU06 } \\
170.1\end{array}$ & $\begin{array}{c}\text { AAU06 } \\
175.1\end{array}$ & $\begin{array}{l}\text { BAE80 } \\
201.1\end{array}$ & $\begin{array}{l}\text { BAD89 } \\
713.1\end{array}$ & $\begin{array}{l}\text { BAD89 } \\
703.1\end{array}$ & $\begin{array}{l}\text { BAD89 } \\
694.1\end{array}$ & $\begin{array}{c}\text { ABR14 } \\
770.1\end{array}$ \\
\hline Ala $(A)$ & 1.8 & 3.0 & 3.0 & 3.0 & 3.2 & 3.0 & 3.0 & 3.0 & 3.0 & 2.4 \\
\hline $\operatorname{Arg}(R)$ & 6.0 & 6.3 & 6.0 & 6.5 & 6.3 & 6.3 & 6.3 & 6.5 & 6.3 & 4.8 \\
\hline Asn (N) & 5.4 & 6.0 & 5.8 & 5.8 & 5.8 & 5.8 & 5.8 & 5.8 & 5.8 & 5.6 \\
\hline Asp (D) & 3.6 & 3.2 & 3.6 & 3.6 & 3.6 & 3.6 & 3.6 & 3.6 & 3.6 & 2.8 \\
\hline Cys $(C)$ & 0.6 & 1.2 & 1.2 & 1.2 & 1.0 & 1.0 & 1.0 & 1.0 & 1.0 & 0.6 \\
\hline $\mathrm{G} \ln (\mathrm{Q})$ & 4.8 & 3.4 & 3.8 & 3.4 & 3.4 & 3.4 & 3.4 & 3.4 & 3.4 & 3.4 \\
\hline Glu (E) & 3.0 & 5.0 & 5.0 & 5.0 & 4.8 & 5.0 & 5.0 & 5.0 & 5.0 & 4.6 \\
\hline Gly (G) & 2.4 & 3.4 & 3.4 & 3.4 & 3.6 & 3.4 & 3.4 & 3.2 & 3.4 & 3.0 \\
\hline His $(\mathrm{H})$ & 2.4 & 4.2 & 3.6 & 4.0 & 3.8 & 3.8 & 3.8 & 3.8 & 3.8 & 3.2 \\
\hline Ile $(\mathrm{I})$ & 6.6 & 8.7 & 8.5 & 8.7 & 3.7 & 8.1 & 8.3 & 8.3 & 8.3 & 7.5 \\
\hline Leu (L) & 12.1 & 12.1 & 12.1 & 12.1 & 12.3 & 12.3 & 12.3 & 12.3 & 12.3 & 11.1 \\
\hline Lys (K) & 10.2 & 5.8 & 6.0 & 5.8 & 5.8 & 5.8 & 5.8 & 5.8 & 5.8 & 4.2 \\
\hline Met (M) & 1.8 & 1.4 & 1.4 & 1.4 & 1.4 & 1.4 & 1.4 & 1.4 & 1.4 & 1.4 \\
\hline Phe $(F)$ & 11.4 & 8.5 & 8.3 & 8.1 & 8.1 & 8.1 & 7.9 & 8.1 & 8.1 & 7.3 \\
\hline Pro $(P)$ & 1.8 & 2.8 & 2.6 & 2.6 & 2.8 & 2.8 & 2.8 & 2.8 & 2.8 & 2.6 \\
\hline Ser (S) & 3.0 & 10.9 & 10.7 & 11.1 & 10.9 & 10.9 & 11.1 & 10.9 & 10.9 & 8.5 \\
\hline Thr (T) & 10.2 & 2.6 & 2.8 & 2.6 & 2.6 & 2.8 & 2.6 & 2.6 & 2.6 & 2.0 \\
\hline $\operatorname{Trp}(\mathrm{W})$ & 3.6 & 1.4 & 1.4 & 1.4 & 1.4 & 1.4 & 1.4 & 1.4 & 1.4 & 1.2 \\
\hline Tyr (Y) & 0.0 & 6.0 & 6.3 & 6.2 & 6.3 & 6.5 & 6.5 & 6.5 & 6.5 & 6.0 \\
\hline Val (V) & 0.0 & 4.4 & 4.6 & 4.4 & 4.4 & 4.8 & 4.8 & 4.8 & 4.8 & 3.8 \\
\hline
\end{tabular}

\section{Kesimpulan}

Hasil pengurutan nukleotida DNA barcode matK menghasilkan 828 pb untuk tumbuhan gedi merah dan tumbuhan gedi hijau. Dari hasil sekuens DNA barcode matK dari gedi merah dan gedi hijau menunjukan kode barcode DNA dari gedi merah dan gedi hijau memiliki tingkat kemiripan yang tinggi, yaitu $>95 \%$. Kesepuluh matK tumbuhan gedi yang dianalisis, semuanya bersifat hidrofobik.

\section{Daftar Pustaka}

Bourdy, G. and A. Walter. 1992. Materniity and Medicinal Plants in Vanuatu I. The Cycle of Reproduction. J. Ethnopharmacology. 37 : 179196.

Cowan, R. S. and M. F. Fay. 2012. Challenge in The DNA Barcoding of Material Plant. Springer Science, New York.

Edgar, R.C. 2004. MUSCLE: Multiple sequence alignment with high accuracy and high throughput.Nucleic Acid Res.5 : 1792-1797.

Hidayati, N. dan R. Dermawan. 2012. Tomat Unggul. Penebar Swadaya, Jakarta.

Kolondam, B. J., E. Lengkong dan J. Polii-Mandang. 2012. Barcode DNA Berdasarkan Gen rbcL dan matK Anggrek Payus Limondok (Phalus tancarvilleae). J. Bioslogos. 2: 55-62.
Krismawati, A. dan E. Sabran. 2004. Pengelolaan sumber daya genetik tanaman obat spesifik kalimantan tengah. Buletin Plasma Nutfah. 12 : 16-23.

Kress, W. J., K. J. Wurdack, E. A. Zimmer, L. A. Weigt and D. H. Janzen. 2005. Use of DNA Barcodes to Identify Flowering Plants. PNAS. 102: 8369-8374.

Mamahit, L. P. 2009. Satu Senyawa Steroid dari Daun Gedi (Abelmoschus manihot L. Medik.) asal Sulawesi Utara. Chemistry Pogres. 2 : 33-38.

Mamahit, L.P dan N.H. Soekamto. 2010. Satu Senyawa Asam Organik yang Diisolasi dari Daun Gedi (Abelmoschus manihot L. Medik). Chemistry Progress. 3 : 42-45.

Morris, R. 2006. Plant for A Future: Edible, Medicinal and Useful Plants for A Healthier Word (Online), (www.ptaf.org/database/plants, http://books. google.co.id) [diakses 29 april 2014].

Radford, S. E. and C. M. Dobson. 1999. From Computer Simulations to Human Disease: Emerging Themes in Protein Folding. Cell. 97: 291-296.

Ratnasingham, S dan PDN. Hebert. 2007. BOLD: The Barcode of Life Data System. Molec. Ecology Notes. 7: 355-364.

Suoth, E., H. Kaempe dan A. Tampi. 2013. Evaluasi Kandungan Total Polifenol dan Isolasi senyawa Flavonoid Pada Daun Gedi Merah (Abelmoschus manihot L.). Chemistry Pogress. 6 : 86-91 